\title{
O SACRIFÍCIO DA LITERATURA
}

\author{
THE SACRIFICE OF LITERATURE \\ Marcos P. Natali \\ Universidade de São Paulo \\ São Paulo, SP, Brasil
}

\section{Resumo}

Partindo da leitura de um trecho da Circonfissáo de Jacques Derrida, o trabalho revisita a questão do sacrifício, agora tendo em vista sua possível contribuição para uma reflexão sobre os estudos literários no presente. Se o sacrifício é o anúncio de uma escolha, a estrutura sacrificial pode ser útil para pensar a literatura em suas relaçóes com demandas de diversas naturezas, ressaltando eventuais semelhanças entre a teoria literária e a teologia em suas respostas à diferença. A leitura do livro de Derrida, texto escrito durante doença de sua mãe, permite que se avalie como o autor imagina que a literatura responde a dilemas éticos presentes na escrita de qualquer texto.

\section{Abstract}

Drawing on a reading of an excerpt from Jacques Derrida's Circonfession, the paper revisits the question of sacrifice, exploring in this case its possible contributions to a reflection on contemporary literary studies. If sacrifice is the declaration of a choice, the sacrificial structure may be useful in thinking about literature and its relations with demands of different sorts, highlighting possible similarities between literary theory and theology in their responses to difference. Reading Derrida's book, a text written during an illness endured by his mother, allows the paper to evaluate how literature responds to the ethical dilemmas present in every text.

\section{Résumé}

A partir de la lecture d'un extrait de Circonfession de Jacques Derrida, ce travail reprend la question du sacrifice pour y évaluer maintenant une contribution possible pour une réflexion sur les études littéraires aujourd'hui. Si le sacrifice est l'annonce d'un choix, la structure sacrificielle peut s'avérer utile pour penser la littérature dans ses relations avec les demandes de diverses natures, moyennant la mise en valeur d'éventuelles similitudes entre la théorie littéraire et la théologie dans leurs réponses à la différence. La lecture du livre de Derrida, texte écrit pendant la maladie de sa mère, permet d'évaluer dans quelle mesure l'auteur imagine que la littérature répond aux dilemmes éthiques présents dans l'écriture de tout texte.
Palavras-chave: Conceito de literatura, Jacques Derrida, sacrifício.

Keywords: Concept of literature, Jacques Derrida, sacrifice.

Mots-cles: Concept de littérature, Jacques Derrida, sacrifice. 
* (DERRIDA, Jacques. «Circonfissão». In: BENNINGTON, Geoffrey e DERRIDA, Jacques. Jacques Derrida. Trad. A. Skinner. Rio de Janeiro: Jorge Zahar, 1996: 34-35.)

* (KIERKEGAARD, Søren Fear and trembling. Trad. $\mathrm{H}$. V. Hong e E. H. Hong. Princeton: Princeton University Press, 1983: 59.)
No começo da sétima perífrase da Circonfissão de Jacques Derrida, texto escrito de janeiro de 1989 a abril de 1990, durante período que o autor já acreditava ser a agonia de sua máe, encontra-se a seguinte confidência: "entre outros remorsos relacionados à minha mãe, sinto-me culpadíssimo por publicar o seu fim, por exibir seus últimos suspiros e pior ainda, com finalidades que alguns poderiam julgar literárias". ${ }^{*}$

Seria necessário ler com calma cada um dos movimentos que se sucedem no interior deste breve trecho. Haveria que se perguntar, desde já, por que, e em relaçáo a quê, seria pior transformar a agonia do outro em literatura, narrando e exibindo-a justamente por meio de um relato literário. Ou então: por que a presença de uma "finalidade" ou "intenção" especificamente literária seria capaz de gerar, num autor, sentimentos de culpa? Ou melhor, para ser ainda mais preciso: por que um texto que descreve a expiação de outro suscita em seu autor remorso especial ao revelar-se incapaz de interditar a possibilidade de ser lido como literatura, náo conseguindo se livrar da aparência literária?

1.

Existe um dever absoluto a Deus? É esta a pergunta que o filósofo dinamarquês Søren Kierkegaard se faz, em sua reflexão sobre o relato da exigência que é feita por Deus a Abraão - o sacrifício de seu filho, Isaac.* Kierkegaard imagina que Abraão teria mantido, durante todo o percurso ao monte Moriá, a esperança de que a exigência do sacrifício, no último instante, seria retirada. $\mathrm{E}$, no entanto, caso a interrupção não acontecesse, Abraão estava disposto a levar o ato adiante, chegando efetivamente a levantar a mão contra o filho, sendo finalmente impedido de matá-lo apenas pela intervençâo de um anjo, cuja exortação Abraão escuta e segue.

São muitos os trechos bíblicos em que são requeridas renúncias de diversos tipos, mas a diferença entre a história do filicídio demandado de Abraão e, por exemplo, algo como a exigência do abandono de bens materiais é importante: em relação à riqueza, não haveria qualquer dever ético. É de outra ordem a exigência feita a

\footnotetext{
${ }^{1}$ Em francês, lê-se: «entre autres remords à l'endroit de ma mère, me sens bien coupable de publier sa fin, d'en exhiber les derniers souffles et pis encore, à des fins que d'aucuns pourraient juger littéraires" (DERRIDA, Jacques. "Circonfession». In: DERRIDA, Jacques e BENNINGTON, Geoffrey. Jacques Derrida. Paris: Éditions du Seuil, 1991: 38).
} 
Abraão: não que abandone a família à própria sorte, não que negligencie os filhos ou abdique de protegê-los, não que evite priorizar seus familiares ante a comunidade ou Deus, mas que interrompa violentamente a vida do filho tão esperado e desejado, o único filho, e com as próprias mãos.

Para Kierkegaard, o interesse da história de Abraão e Isaac está precisamente na natureza dessa petição que não pode ser vista senão como um escândalo. $\mathrm{O}$ ato que Abraão está disposto a cometer é uma aberração de tal ordem que desautoriza qualquer cálculo e toda comparação, sendo obscena qualquer avaliação da razoabilidade daquilo que lhe é pedido. O despropósito se fundamenta no fato de que a demanda feita a Abraão requer a transgressão de toda ética, com o estabelecimento além e acima dela de um télos em relação ao qual a ética fica, subitamente, suspensa.* Sendo contrário à ética o ato cobrado de Abraão, relativiza-se a universalidade dela diante do absolutismo do dever a Deus.

É por isso que, para Kierkegaard, a história de Abraão é incompreensível e não deve deixar de ser incompreensível - ou então só poderá ser compreendida à medida que se pode compreender um paradoxo. Na leitura que Kierkegaard faz da passagem bíblica, "ou existe um paradoxo, e o indivíduo particular como indivíduo particular está numa relação com o absoluto, ou Abraão está perdido"* - e estar perdido, aqui, significaria que Abraão seria, ao invés de um devoto, um assassino. Desde a "religiáo", seu ato - o ato que ele se mostra disposto a empreender - é um sacrifício; desde a ética, um assassinato.* Kierkegaard concluirá que, além de ninguém ser capaz de entender Abraáo, e além de seu ato não servir como modelo ou aprendizado, não devendo ser repetido ou apresentado como exemplo, Abraão não terá sequer o louvor reservado a um herói trágico: "O que Abraão alcançou? Ele se manteve fiel a seu amor. Mas qualquer um que ama a Deus não precisa de lágrimas ou admiração; ele se esquece do sofrimento em meio ao amor".*

* (Ibidem: 120.)

* (Ibidem: 30.)

2.

Jacques Rancière dirá que o significado de sacrifício é, simplesmente, escolha.* A definição amplia a relevância, para uma reflexão sobre a relação entre a ética e a estética, de algo que poderia ser chamado de estrutura sacrificial, aquilo que Kierkegaard encontrará também no Evangelho de Mateus: "Ninguém pode servir a dois

* (RANCIÈRE, Jacques. "The Aesthetic Dimension: Aesthetics, Politics, Knowledge". Critical Inquiry, n.36, p. 1-19, outono de 2009: 15.) 
* (KIERKEGAARD, Søren. Fear and trembling. Trad. $\mathrm{H}$. V. Hong e E. H. Hong. Princeton: Princeton University Press, 1983: 59.)

* (LÉVINAS, Emmanuel. Proper Names. Trad. M. Smith. Stanford: Stanford University Press, 1996: 7677.)

* (RANCIÈRE, Jacques. "The Aesthetic Dimension: Aesthetics, Politics, Knowledge". Critical Inquiry, n.36, p. 1-19, outono de 2009: 15.)

* (DERRIDA, Jacques. "Literature in Secret". In: The Gift of Death \& Literature in Secret. Trad. D. Wills. Chicago: University of Chicago Press, 2008: 125-126.)

* (Ibidem: 68.) senhores: ou odiará a um e amará o outro, ou se apegará a um e desprezará o outro" (para que Kierkegaard então imediatamente pergunte: Mas quem pode dizer que náo serve ao mesmo tempo a dois senhores?).* Ao exigir a escolha, uma estrutura sacrificial particular não é diferente de qualquer outra, em relaçóes de qualquer tipo, sempre que alguém se vê obrigado a escolher: ou isto, ou aquilo.

Ao contrário de Kierkegaard, que se detêm, no episódio do sacrifício de Isaac, na suspensão da ética e na interdição da escolha, Emmanuel Lévinas, em sua objeção a Kierkegaard, aponta como giro fundamental no relato bíblico a disposição de Abraão para ouvir a voz do anjo, sendo então conduzido através de seu chamado de volta à esfera da ética. Para Lévinas, é notável que Abraão siga a primeira voz (que é de Deus), dada a aberração da prova exigida, mas é extraordinário, dada sua origem, que ele tenha ouvidos para escutar a segunda exortação, aquela que proporá a suspensão do sacrifício. O movimento crucial na história, para Lévinas, e o que nela é essencial, o ponto mais alto de seu drama, não seria a obediência de Abraão à ordem divina, mas sua prontidão para desobedecer a essa mesma ordem, substituindo-a por outra, pronunciada não por Deus, origem direta da primeira, mas por um anjo (mesmo que anunciado como enviado por Deus). É possível ler na interpretação de Lévinas a sugestão de que o que Abraão sacrifica é na verdade a primeira ordem, traída em benefício da segunda, que lhe é incompatível e a qual prefere.*

Rancière, para quem a escolha de Abraáo fora entre duas traiçóes - traição a Deus, por um lado, e a Isaac, por outro, e ainda a Sarah, sua mãe -, encontrará no relato, e na leitura que Derrida faz dele e de Lévinas, a lição de que não há motivo que leve necessariamente à escolha de Deus ao invés de Isaac e Sarah. Graças ao Deus de Abraão e à configuração inaugurada com ele, indica Rancière, qualquer um pode ocupar o lugar do outro que é absolutamente outro.* Na mesma linha, Derrida, em sua leitura do episódio, se imaginará falando por Abraão, em primeira pessoa, para fazê-lo pedir perdão por ter escutado o chamado de Deus e por tê-lo escolhido e preferido.*

Derrida insiste que, se o relato de Abraão é monstruoso, inconcebível e abominável, e se é crucial que sua monstruosidade não seja diminuída, ao mesmo tempo não há nada mais comum do que o dilema que ele propóe. Há sempre um número infinito de outros a quem sou responsável,* e qualquer resposta ao cha- 
mado ou inclusive ao amor do outro envolve a decisão de sacrificar outros outros, condenando os conceitos de responsabilidade, decisão e dever necessariamente ao paradoxo, ao escândalo e à aporia - outros nomes para sacrifício, propóe Derrida.* Minha responsabilidade além de qualquer cálculo e de toda comparação é simultaneamente e na mesma medida a todos, a cada um dos quais náo tenho porque não dever fidelidade absoluta.

Se tivermos presente que o livro que aqui está sendo lido foi redigido por Derrida durante a enfermidade de sua mãe, tendo como horizonte a possibilidade de sua morte, a questáo passa a ser algo como o seguinte: como devo me comportar nesses momentos finais, nessas horas, dias, semanas, meses, que devem ser vividos, cada um deles, como derradeiros? Diante do leito, qual seria a pesquisa, qual a leitura, qual o texto a ser escrito que justificaria o desvio do olhar do filho, da cama e do olhar da mãe, olhar no qual o filho já está ausente, à página? Qual é a viagem, a palestra, o dever profissional, o "trabalho" que desculparia a ausência do filho?

E não seria em alguma medida a pior de todas as tentaçóes a transformação do trabalho de luto (antecipado e, como sempre, já iniciado, pois como definir quando deve começar o trabalho de luto?) em outro tipo de "trabalho" - o do filósofo, por exemplo, que incorpora seu luto a um livro que escreve sobre si, sob encomenda de uma editora? Não seria esse exercício aglutinador uma forma de não escolher, de não optar, ao se ver diante das demandas da estrutura sacrificial, tentando conciliar trabalho de luto e trabalho filosófico? Não se faz, assim, da necessidade de uma resposta singular e secreta à mãe uma resposta pública, disponível a qualquer leitor interessado - pois o texto será, já se imagina e se anuncia, publicado?

3.

São cenas como essas, em que a fidelidade a uma paixão sugere a possibilidade da suspensão da ética, que quero tomar emprestadas para pensar, mais uma vez, a literatura. Adaptando as indagaçóes apresentadas até aqui, a partir de Abraão, Derrida, Kierkegaard e Lévinas, a pergunta seria: haveria um dever absoluto à literatura? Ou melhor: o que acontece se deslocamos o paradoxo da história de Abraão do domínio religioso para o estético?

Que o movimento seja possível, e que a aproximação tenha alguma utilidade, torna evidente como a tradição literária é her- 
* (DIRETÓRIO ESPIRITUAL DOS MONGES E MONJAS DA CONGREGAÇÃO BRASILEIRA DA ORDEM CISTERCIENSE. Nada antepor ao amor de Cristo. São Paulo: Musa Editora, 2003: 11.)

* (LÉVINAS, Emmanuel. La realidad y su sombra. Trad. A. D. Leiva. Madri: Editorial Trotta, 2001: 66.) deira de uma tradição religiosa, algo visível em seu vocabulário, seus gestos e suas cerimônias, até nas figuras que a cercam (diferentes versóes do sacerdote, do hermeneuta, do místico, do herege, do apóstata). A questão não é nova, como se sabe, embora possa ter no presente um significado diferente daquele que já teve. Mas é, também hoje, a falta de respeito a um dever absoluto o que se parece denunciar sempre que no cotidiano de nossas vidas institucionais - em defesas de teses, concursos públicos, salas de aula - alguém é acusado de possuir devoção insuficiente à literatura, ou um crítico é incriminado por não ter partido em sua análise da obra literária, ou se especula, com desconfiança, que um leitor náo concedeu primazia à obra, sendo guiado na verdade por outros interesses, que podem ser mais ou menos escusos, mas seriam sempre ilegítimos.

"Nada antepor ao amor de Cristo" é parte da Regra de São Bento, texto que rege a vida dos monges beneditinos e define aquilo que deve ter, nas palavras da Regra, "absoluta primazia” na mente de um monge.* Que seja possível adaptar fórmulas como esta e utilizá-las para descrever o funcionamento institucional e teórico dos estudos literários ajuda a esclarecer a aproximação, feita por Lévinas e outros, em história que também é antiga, entre arte e idolatria.* Para Lévinas, ao não reconhecer qualquer compromisso além ou maior do que ela, a arte se tornaria o simulacro de uma experiência religiosa. Fechando-se em si, buscando ser um fim em si mesma, a arte inclusive negaria a possibilidade da salvação, essa abertura ao porvir, pois o "mundo por acabar" é substituído pelo acabamento da obra. Assim, "em termos teológicos", a arte não pertenceria à ordem da revelação, não havendo nada além dela, e se transformaria em ídolo. (A diferença da "imagem religiosa” seria que nela o pressuposto é que o mais importante não está lá, a contemplação da obra não podendo se restringir à celebração de sua existência.) Para Lévinas, como ausência de resposta às demandas do outro, e ao se recusar a reconhecer qualquer mestre e isentar o artista de qualquer dever, a arte manifestaria o desejo de se tornar imune a toda acusação, nada podendo lhe ser imputado ou atribuído.

4.

Para nos aproximarmos de uma compreensão do sentimento de culpa confessado por Derrida seria necessário entendermos primeiro o que significa, afinal, literatura em seu pensamento - o 
que nos levaria, mais do que a uma conceitualização única, a um mosaico de figurações interligadas. De todo modo, as concepçóes de literatura que predominam nos textos de Derrida não são as de Lévinas, estando ausente delas aquilo que Blanchot, escrevendo sobre Lévinas, descreveu como uma desconfiança constante diante da arte. Ao contrário, tende a ser bastante positivo, e por vezes até mesmo eufórico e arrebatado, o que Derrida tem a dizer sobre a literatura. Derrida não hesitará em dizer que a literatura "É a coisa mais interessante do mundo, talvez até mais interessante do que o mundo".* Como em outros textos, o interesse pela literatura virá de sua capacidade para dramatizar características encontradas também em outros discursos, além de seu poder de formular perguntas difíceis à filosofia. A literatura é justamente aquilo que, diante da indagação filosófica - "O que é 'literatura??" -, desestabiliza a primeira parte da pergunta - o "O que é...".*

Já em suas Paixóes, Derrida revelará, também como uma espécie de confidência, o desejo de "confiar ou confirmar [seu] gosto (provavelmente incondicional) pela literatura, mais precisamente, pela escritura literária”.* A profissão de fé feita em confiança insinua, neste texto posterior à Circonfissão, a presença de um segredo, o que será confirmado de outro modo quando, em seguida, se assegura que o interesse pela literatura não viria dela "em si", mas justamente pelo lugar que ela reserva para o segredo. Volta e meia retorna nos textos de Derrida algo como uma apologia do segredo e do direito ao silêncio, com a literatura apresentada como modelar em sua recusa a responder a exigências de diversas ordens, o princípio do direito de dizer tudo que ela pressupóe sendo também, afinal, o direito a não dizer.

Nâo seria impossível desenvolver o raciocínio até a conclusão de que a literatura seria, então, o tipo de texto mais adequado para receber uma elegia, dado que ela tem como pressuposto estar atravessada de algum modo pela ausência. Mas não é esse o argumento sugerido na citação reproduzida no início deste texto, à qual será necessário voltar: "entre outros remorsos relacionados à minha mãe, sinto-me culpadíssimo por publicar o seu fim, por exibir seus últimos suspiros e pior ainda, com finalidades que alguns poderiam julgar literárias." A culpa, anunciada como superlativa, está relacionada ao ato de tornar pública a intimidade da mãe, estando ela em situação de extrema vulnerabilidade. Certamente não faltam episódios no relato para justificar a acusação de exposição
* (DERRIDA, Jacques. "'This Strange Institution Called Literature': An Interview with Jacques Derrida." Acts of Literature. Nova York: Routledge, 1992: 47.)

* (ATTRIDGE, Derek. "Derrida and the Questioning of Literature". Acts of Literature. Nova York: Routledge, 1992: 2.)

* (DERRIDA, Jacques. Paixões. Trad. Loris Z. Machado. Campinas: Papirus, 1995: 46.) 
excessiva do outro: Derrida narrará frases incoerentes proferidas pela mãe, já doente de Alzheimer, descreverá as chagas que tomam seu corpo e relatará episódios constrangedores em que ela se despe diante dos outros, inclusive do filho, explicando que o faz porque tem charme e é atraente. Não se trata, portanto, de texto discreto e precavido - até onde o leitor pode ver -, e essas cenas, junto a outras que vão se acumulando e que o relato aos poucos expóe, seriam razão suficiente para explicar o surgimento de sentimentos de culpa. Se o questionamento quanto ao valor da visibilidade e da publicidade é frequente em Derrida, neste texto a dúvida ganha a seguinte forma: em nome de quê ou de quem eu teria o direito de tornar públicos os últimos momentos da vida de minha mãe? (A ressalva importante é, evidentemente, que não há como saber se "tudo" foi, de fato, publicado, que este foi o texto escrito durante o luto, sem rasuras, que não há outro, oculto e secreto, escrito apenas para ela. Mesmo no momento em que confesso, afinal, algo se mantém secreto dentro de mim.)

A interrupção da escrita pela novidade temida, e com ela a irrupção de um acontecimento que se situaria acima de qualquer outro, representaria por um instante o fim da necessidade da escolha e assim também o fim da culpa, o acontecimento sendo nesse sentido também uma suspensão da ética. Mas é possível que esse acontecimento não dure mais do que um instante, e o momento de certeza e de fim de todo cálculo, assim como chegou, se esvaia. E então, claro, a questão se inverteria: quanto tempo deve durar a interrupção, a pausa na vida? Até quando se deve calar, até quando se deve abdicar de escrever? Até quando resistir a apanhar o livro para a leitura, secando as lágrimas que impedem a leitura? A pergunta não é mais quando começa a suspensão da escolha, mas até quando ela deve durar.

Mas a confissão de remorso parece se referir também a um problema de outra natureza, uma questâo relacionada à possibilidade de uma avaliaçáo que associe a intenção do escritor à literatura. (E seria possível retomar a história da recepção da obra de Derrida a partir das incriminaçóes que identificaram nela a presença de objetivos literários ao invés de propriamente filosóficos, com as denúncias apontando nos textos do autor, com tom incriminador, seu caráter lúdico, a preponderância do prazer discursivo, a importância do jogo verbal, a opacidade, até seu caráter "sentimental" - ou seja, algo neles definido como "literário" demais, e filosófico 
de menos, justificando a desconfiança em relação à sua responsabilidade, fidelidade e finalidade.) $\mathrm{O}$ impasse em que se encontra o autor reside no fato de que, como ele mesmo sustentou tantas vezes, não há como impedir (ou garantir) que um texto seja lido como literatura. Nenhum texto conseguiria, desde seu interior, antecipar e prevenir uma leitura "literária", imunizando-se contra a percepção, elogiosa ou acusatória, de que possui características literárias. (Talvez fosse mais dolorosa, no caso em questão, a leitura elogiosa, que celebre o texto por suas virtudes estéticas.)

A questão está mais uma vez vinculada ao fim: o fim da vida da mãe, que o filho descreve (e sabe que depois divulgará), e as finalidades que levam o escritor a escrever, ou seja, os fins que podem levar um filho a narrar a agonia da mãe (e dessa maneira). Ganha relevância, neste sentido, que a culpa seja apresentada como o resultado não exatamente do ato de escrever ou narrar a morte da mãe, mas de publicar o seu resultado: "sinto-me culpadíssimo por publicar o seu fim”. É a existência de uma finalidade pública, já antecipada no presente da escrita, o elemento desencadeador do remorso, como se o receio fosse o da revelação de um segredo alheio.

Num dos textos em que Derrida associa a literatura ao segredo, ao mesmo tempo em que ressalva que a possibilidade do aparecimento de uma leitura literária existe para qualquer texto, a culpa é associada a uma possível genealogia abraâmica da literatura, o literário visto como a tentativa de secularização de uma revelação santa ou divina.* A literatura seria assim mais uma versão do sacrifício praticado por Isaac, dessacralizando as sagradas escrituras e expondo-as ao mundo. Com esse sacrifício, a literatura gera espectros dos textos sagrados, contaminando com fantasmas de seu ente amado e sacrificado (sacrificado por ser amado) o espaço supostamente secularizado da modernidade. As ruínas desse processo seriam visíveis em nossa relação com a obra literária, nossa atenção a seus detalhes e esperança no aparecimento durante a experiência de leitura de uma espécie de revelação. A literatura, sugere Derrida, passa a ser sempre um pedido de perdáo pela traição de sua origem santa (quando não é, seria possível acrescentar, um pedido de perdão por sua origem, isto é, por não tê-la traído suficientemente e preservar demasiados elementos religiosos).

A pergunta a fazer, diante desta Circonfissão, é: o que havia, nas peculiares circunstâncias do contexto de sua produção, para que o costumeiro entusiasmo do autor pela literatura encontrasse
*(DERRIDA, Jacques. "Literature in Secret". In: The Gift of Death \& Literature in Secret. Trad. D. Wills. Chicago: University of Chicago Press, 2008: 156 .) 
* (DERRIDA, Jacques. The Work of Mourning. Trad. Pascale-Anne Brault e Michael Naas. Chicago: University of Chicago Press, 2001: 51.)

* (Ibidem: 38.)

* (Ibidem: 33-34.) um limite? Em outras palavras, se é frequente na obra de Derrida a identificação e a análise, em textos alheios, da preservação sob outras formas do transcendente ou do absoluto, por que um gesto semelhante, em relação aos restos de transcendência na relação com a literatura, surge justamente neste texto?

A questão diz respeito à busca do gênero e da forma discursiva menos irresponsáveis na narração da agonia do outro, os riscos específicos presentes na elegia rondando qualquer comemoração e presentes até em "simples atos de fidelidade", como dirá Derrida.* A propósito de Roland Barthes, após sua morte, Derrida escreverá que o mimetismo do estilo da escrita do autor falecido é um dever, e ao mesmo tempo a pior das tentações, "a mais indecente e a mais assassina".* Afinal, se é certo que não é senão através dos vivos que podem falar os mortos, nosso dever doloroso é ressaltar a insuficiência dessa fala através de mim que é sempre mais "eu”, mais minha, do que eu gostaria. Por isso, a cada momento devemos reconhecer que o outro "se foi para sempre, que está irremediavelmente ausente", pois seria uma forma de infidelidade iludirse e "acreditar que o outro vivendo em nós está vivendo em si".* Entre os riscos da elegia está, portanto, a suposição de que sabemos o que diria o ausente diante de um novo assunto ou acontecimento, ou até mesmo o que diria se voltasse a assunto antigo, isto é, a suposição de que sabemos precisamente o que perdemos com a ausência, quando a tragédia é justamente termos perdido a possibilidade do gesto inesperado que vem do outro.

Que esses dilemas tenham sido transformados em um gênero, e que a elegia seja um gênero entre outros, é, evidentemente, o primeiro dos problemas, como observou Derrida. Diante da mãe moribunda, ele descreve o desejo de dizer uma palavra única e nova, para fugir de todo programa e de toda citação - e no entanto basta começar a falar que já se percebe citando, temendo inclusive inserirse na conhecida série de depoimentos de escritores franceses sobre suas mães. ${ }^{2}$ Deve-se então abandonar de uma vez por todas a ele-

\footnotetext{
${ }^{2}$ Se Derrida teme ver-se na série de textos escritos por franceses a respeito da morte da mãe, e se sabe, enquanto escreve, que não terá como evitar a inclusão de seu livro nessa sequência (mais uma morte, mais um relato...), inclusive seu recuo em relação à literatura, diante de circunstâncias como as da cena de escrita de sua Circonfissão, poderia ser inscrito numa série pré-existente. Roland Barthes, em seu Diário do luto, também descreve o medo de, em meio à redação de suas fichas, descobrir-se fazendo literatura: "Não quero falar disso por medo de fazer literatura - ou sem estar certo de que não o será” (BARTHES, Roland. Diá-
} 
gia, a exposição do segredo, a confidência e o luto público? Na continuação da citação que abre este texto, Derrida pergunta: "o que fazer, não me sentiria eu igualmente culpado, não o seria na verdade caso escrevesse aqui sobre mim sem resguardar o menor traço dela, deixando-a morrer no fundo de um outro ora?”.*

Diante de um "mestre" da elegia que também é um apaixonado pela literatura, entender a culpa que surge diante da possibilidade de que sua "elegia" particular seja entendida como literatura equivale a imaginar o que aconteceria se a literatura, pensada não como uma essência, mas como uma série de relaçóes, fosse definida não em oposição à história ou à filosofia, como é corrente, mas em contraste com a elegia. Exigiria imaginar, portanto, como a literatura responde aos riscos de toda elegia: o risco de voltar a si, o risco do narcisismo, o risco de passar a impressão de que o outro em mim é o outro em si.

Se a literatura pode surgir sempre que não é possível determinar se falo de alguma coisa ou da possibilidade de falar de qualquer coisa, a diferença do texto elegíaco estaria no fato de seu esforço dirigir-se a outra direção, na tentativa de determinar o mais precisamente possível aquele de quem se fala, a partir do evento de sua morte, definindo até onde for possível a referência e restringindo a instabilidade do discurso. Diferentemente da literatura, definida por Derrida em outro contexto como todo texto cujos conteúdo, sentido, referente, assinatura e destinatário não são realidades determináveis, * a tarefa da elegia é buscar escapar da indefinição da referência e também do "você" a quem se fala, no esforço por continuar um diálogo que chega à sua última troca, muitas vezes diante do corpo do destinatário. Em seu Adeus a Emmanuel Lévinas, Derrida observará que

Frequentemente, aqueles que se apresentam então para falar, para falar publicamente, interrompendo assim o murmúrio animado, as trocas secretas ou íntimas que sempre nos ligam, em nosso foro interior, ao amigo ou ao mestre morto, frequentemente aqueles que fazem então escutar sua voz num cemitério, dirigem-se diretamente, em linha reta, àquele de quem se diz que não está mais, que não está mais vivo, que não está mais aqui, que não responderá mais. As lágrimas na voz mostram uma certa intimidade com o outro que guarda silêncio, elas o interpelam sem desvios ou mediação, elas o apostrofam, elas o saúdam também ou se confiam a ele. [...] Trata-se sobretudo de fazer passar a palavra, lá onde as palavras nos faltam, e
* (DERRIDA, Jacques. «Circonfissão». In: BENNINGTON, Geoffrey e DERRIDA, Jacques. Jacques Derrida. Trad. A. Skinner. Rio de Janeiro: Jorge Zahar, 1996: 35.)

* (DERRIDA, Jacques. "Literature in Secret". In: The Gift of Death \& Literature in Secret. Trad. D. Wills. Chicago: University of Chicago Press, 2008: 131.)

rio de luto. Trad. Leyla Perrone-Moisés. São Paulo: Martins Fontes, 2011: 23). 
* (DERRIDA, Jacques. Adeus a Emmanuel Lévinas. Trad. Fábio Landa. São Paulo: Perspectiva, 2004: 16.)

* (DERRIDA, Jacques. «Circonfissão». In: BENNINGTON, Geoffrey e DERRIDA, Jacques. Jacques Derrida. Trad. A. Skinner. Rio de Janeiro: Jorge Zahar, 1996: 41.)

* (MAGALHÃES, Milena e SISCAR, Marcos. "A circunavegação autobiográfica". In: NIGRO, Cláudia, BUSATO, Susanna, e AMORIM, Orlando. (orgs). Literatura e representações do eu. São Paulo: Ed. UNESP, 2010: 101.)

* (DERRIDA, Jacques. «Circonfissão». In: BENNINGTON, Geoffrey e DERRIDA, Jacques. Jacques Derrida. Trad. A. Skinner. Rio de Janeiro: Jorge Zahar, 1996: 48.)

* (Ibidem: 114.) porque toda linguagem que se voltasse sobre si-mesma, sobre nós, pareceria indecente, como um discurso reflexivo que retornaria para a comunidade ferida, para seu consolo ou seu luto, para o que se denomina por essa expressão confusa e terrível o "trabalho de luto". Ocupada consigo mesma, tal palavra correria o risco, neste retorno, de desviar-se do que é aqui nossa lei - e a lei como retidão: falar diretamente, dirigir-se diretamente ao outro, e falar ao outro que amamos e admiramos, antes de falar dele.*

Também a Circonfissão parece desejar ser um texto escrito não sobre, mas para a mãe. Se o perigo é o retorno a si, o que retorna também é a sombra da culpa do ato de escrever, com a aparição de círculos intermináveis de outros destinatários, em pé em volta da mãe, sendo impossível, em última instância, impedir a disseminação do texto. Em alguma medida, "sempre se pede perdáo quando se escreve",* a culpa advindo de "não se escrever apenas para um; de não haver um único destinatário, pois mesmo quando imaginamos apenas um, haverá sempre o risco de que o envio chegue a um outro"**

5.

A difícil passagem do sobre ao para - de resto nunca garantida, como não há como garantir que a elegia não será também ela tomada pela dissimulação, o simulacro, a mentira, o perjúrio e a ficção - será o trabalho ao qual se dedicará o texto, sugerindo a comparação com a oração, outro gênero em que o problema do destinatário - a quem falo, afinal? - é fundamental. Repete-se o dilema de Santo Agostinho, cujas Confissóes o texto de Derrida também reproduz e glosa: confessar a Deus para quê, se tudo já é conhecido por Ele? E, no entanto, "Rezo, como não deixei de fazer a vida inteira”, escreverá Derrida, ${ }^{*}$ enquanto o destinatário de sua singular oraçáo vai deslizando de Deus a Santo Agostinho a Geoffrey Bennington à sua mãe.

A mãe de Derrida, antes de cair no silêncio precoce que antecipou seu silêncio definitivo, costumava perguntar a terceiros se o filho ainda acreditava em Deus. Desconfiada de que nos livros de Derrida, que ela nunca lera, haveria uma resposta, ${ }^{*}$ preocupa-se, como Santa Mônica, mãe de Santo Agostinho e protagonista de suas Confissóes, com a fé do filho. As confidências de Derrida nessas novas confissóes podem ser lidas como uma resposta à interrogação da mãe, com a questão da sobrevivência da fé atravessando, de 
maneira angustiada, o texto de Derrida: "nem minha mãe entende minha religião", lamentará ele.*

Se o enredo das Confissóes de Santo Agostinho será que ele, contra a "própria vontade", vai chorar a morte da mãe, dando provas de seu apego à vida terrena ao ser tomado pelo afeto pela máe e descobrir-se incapaz de deter as lágrimas que se apoderam dele e revelam a ambivalência de seu desejo, o temor de Derrida na Circonfissáo parece ser outro: o de não chorar a mãe suficientemente. Derrida não consegue ter certeza, de uma vez por todas, se escrever o aproxima ou afasta da mortalidade, do humano e da mãe. Ele não é capaz de definir, terminantemente, aonde se dirige, exatamente, sua fidelidade - se à mãe, se a outro (a si mesmo, à filosofia, à literatura, a "meu deus", como escreve): "escrevo que há demasiado amor em minha vida, sublinhando demasiado, o melhor e o pior, isso seria verdade, o amor terá vencido minha resistência”.*

Derrida sequer consegue, sem reservas e sem gaguejar, dizer-se ateu e professar o próprio ateísmo, situação que levará, em Força de lei, a uma historização inclusive do questionamento, ${ }^{*}$ interditando a saída da afirmação de uma fidelidade sem limites ou exceçóes ao questionamento, à dúvida, à incredulidade e ao "ateísmo" e abrindo-se à possibilidade de uma reflexão sobre possíveis limites ao princípio do direito a dizer tudo e, consequentemente, da democracia.

"O que amo?", Santo Agostinho se perguntará. O que amo, que amo acima de tudo? "Que amo, então, quando amo o meu Deus? Quem é aquele que está acima de minha alma?”* Imaginemos perguntas adaptadas das de Santo Agostinho para a discussão empreendida aqui: o que amo, quando amo a literatura? Funcionaria a declaração (e a exigência) de paixão pela literatura como uma espécie de metafísica ou teologia secularizada (e portanto permitida)? Seria essa uma devoção que hoje, ao ser enunciada, não requereria um pedido público de desculpas (ao contrário das referências a Deus que, segundo Lévinas, agora precisam ser acompanhadas de um pedido de perdão)?*

Os riscos que cercam o caráter ("provavelmente"!) incondicional da paixão de Derrida pela literatura, ela que é possivelmente até mais interessante do que o mundo, podem ajudar a explicar o surgimento da ambivalência e da culpa na Circonfissão, texto que procura anular o próprio interesse - "busco desinteressar-me de mim..." -, texto em que o mundo significa, sobretudo, a mãe. Ao mesmo tempo, ronda o texto a ideia de que é também essa espécie

* (DERRIDA, Jacques. «Circonfissão». In: BENNINGTON, Geoffrey e DERRIDA, Jacques. Jacques Derrida. Trad. A. Skinner. Rio de Janeiro: Jorge Zahar, 1996: 114.)

*(Ibidem: 115-116.)

* (DERRIDA, Jacques. Força de lei: o fundamento místico da autoridade. Trad. Leyla Perrone-Moisés. São Paulo: Martins Fontes, 2007: 13.)

* (AGOStinHO. Confissões. Trad. Maria Luiza Jardim Amarante. São Paulo: Paulus, 1984: 273.)

* (DERRIDA, Jacques. "Literature in Secret". In: The Gift of Death \& Literature in Secret. Trad. D. Wills. Chicago: University of Chicago Press, 2008: 148.)

* (DERRIDA, Jacques. «Circonfissão». In: BENNINGTON, Geoffrey e DERRIDA, Jacques. Jacques Derrida. Trad. A. Skinner. Rio de Janeiro: Jorge Zahar, 1996: 135.) 
de libertação concedida pela perda da consciência da mãe o que permite a escrita desse estranho texto, essa confidência agora definitivamente além do alcance da leitura da mãe.

6.

Como não se pode ler uma obra $\mathrm{em} \mathrm{si,} \mathrm{e} \mathrm{uma} \mathrm{obra} \mathrm{literária}$ não pode, suspendendo toda referência, ser apenas sobre a literatura, talvez toda paixão pela literatura seja também imediatamente deslocada. E, no entanto, continua a ser algo como uma fidelidade absoluta a ela - antes e além de qualquer outro - o que se exige em determinadas circunstâncias. Exigir fidelidade à literatura, exigir a declaração da paixão por ela, ter essa declaração como condiçâa de diálogo, talvez cobrar provas de devoção - são formas de violência que encenam mais uma vez a prova absoluta exigida de Abraão. A exigência da concessão de primazia - epistemológica, ética, prática - à literatura é a cobrança de um comprometimento e de uma decisão anterior a qualquer relação e a qualquer escolha, anterior, inclusive, ao pensamento.

Evidentemente, há como defender, em situaçóes específicas, a expansão da literatura, com tudo o que isto implica - a consolidação de uma determinada subjetividade, os prazeres e deveres da interioridade etc. Mas afirmar que a defesa é possível equivale a dizer também que ela é necessária, precisando então ser pensada e formulada, em cada caso particular, a literatura sendo algo a ser escolhido ou não, de acordo com as circunstâncias. Seria preciso decidir, a cada momento e diante de cada oposição, qual é o sacrifício mais justo, menos violento e sangrento, e quais as formas menos

* (MCCORMICK, John. "Derrida on Law; Or, Poststructuralism Gets Serious". Political Theory, v. 29, n. 3, junho de 2001: 402.) coercivas de sacrifício.*

São conjunturas como esta, vistas por vezes como uma hesitaçấo diante da possibilidade de resolver um dilema de uma vez por todas, que parecem levar alguns críticos a apontarem em Derrida o enfraquecimento da possibilidade de justiça. Ao se recusar a decidir de antemão, Derrida permitiria que outros, possivelmente mais injustos, decidissem por ele. Entretanto, a questão para Derrida parece ser a violência arbitrária, latente ou não, necessária para a fundação de qualquer justiça, esse reconhecimento sendo a condição de possibilidade de outra justiça, menos violenta. Retirar a interdição do reconhecimento da força necessária para a instauração da instituição da literatura (mesmo sendo ela uma instituição 
"anti-institucional") permitiria que fosse contada sua história, e de modo que ficasse claro que esta história ainda está em aberto.

Diante do medo de sacrificar a mãe em proveito da literatura, o autor da Circonfissão sonhará com a transformação da própria escrita, através da interferência do acontecimento trágico: "caso este livro não me transforme radicalmente" terei fracassado, escreverá ele.* Como pode tudo seguir como antes, como podem as palavras continuarem as mesmas? Se é certo que sempre se pede perdão quando se escreve, a separação, agora definitiva, da mãe, e o afastamento final da língua materna darão outra dimensão à clemência a ser pedida pela "blasfêmia" em que consiste o ato de escrever: pede-se perdão pelo sacrifício cometido, por haver sobrevivido, por ter levado adiante o trabalho do luto, por haver transformado o luto em um trabalho.

Se a escrita "literária" insiste em ser sempre outra coisa, desde sempre impura e contaminada por outras línguas, dramatizando em seu corpo a impossibilidade de fixação do sentido, do destinatário e da origem, o gênero que aqui está sendo chamado de elegia dedicaria suas forças à tentativa de concentrar o dever e a paixão, buscando restringir a disseminação, a digressão e a instabilidade. A escrita da Circonfissáo busca portanto ensaiar a passagem do sobre ao para, dirigindo-se à mãe e definindo-a como destinatária, além de se empenhar em sua demarcação também como procedência. A cena é, desse modo, uma em que já há espectros demais, liberdade demais, fluidez demais, rupturas demais, distância demais, gerando o desejo da restrição da instabilidade do discurso. A angústia vem do fato de que a tarefa é empreendida por alguém que reconheceu, em tantos textos anteriores a este, que o simples ato de dar um nome é já a demonstração da mortalidade do outro.

7.

O movimento mais surpreendente nessa espécie de elegia escrita por Derrida talvez seja o registro, pelo filho, de acusaçóes dirigidas à mãe, com o texto até tomando o aspecto de uma improvável confissão da mãe, que revelaria seus "tão pesados segredos", dos quais o filho é "herdeiro à revelia". Atribuído à mãe o "suposto crime" da circuncisão do filho, este é narrado por meio de um relato que o aproxima do assassinato ritual: "se aquela que deseja, às vezes comete a circuncisão, pactua com o desejo inibido do assassinato da
* (DERRIDA, Jacques. «Circonfissão». In: BENNINGTON, Geoffrey e DERRIDA, Jacques. Jacques Derrida. Trad. A. Skinner. Rio de Janeiro: Jorge Zahar, 1996: 62.) 
* (DERRIDA, Jacques. «Circonfissão». In: BENNINGTON, Geoffrey e DERRIDA, Jacques. Jacques Derrida. Trad. A. Skinner. Rio de Janeiro: Jorge Zahar, 1996: 134-135.)

* (Ibidem: 202.)

* (DERRIDA, Jacques. "'This Strange Institution Called Literature': An Interview with Jacques Derrida." Acts of Literature. Nova York: Routledge, 1992: 38.)

* (Ibidem: 58.) criança, ela se encontra exatamente na posição de obsequência”.* Como na cena no monte Moriá, interrompida com Isaac já amarrado sobre a lenha, também na circuncisão trata-se de erguer a máo contra o filho: "Ele orava ao sol mãos às costas, à proximidade tanto do sacrifício quanto de sua interrupção, mão erguida sobre mim, são muitos em torno do mohel, olham por entre minhas pernas, chamam-me e nada ouço".* (As mulheres, enquanto isso, "estão no outro cômodo", e o ressentimento é também por ter sido abandonado, pela mãe e por todas elas, à própria sorte, no mundo dos homens.) Se no Gênesis a única fala de Isaac, o quase sacrificado, em todo o episódio é a pergunta ao pai - "Meu pai, aqui estão o fogo e a lenha: onde está o cordeiro para o holocausto?” -, nesses trechos da Circonfissão é como se emergisse a voz de Isaac, agora a par do segredo do pai, mesclada às indagaçóes que Derrida dirige a todos aqueles dispostos a levá-lo à pedra sacrificial. $\mathrm{O}$ resultado é a dificuldade de determinar quem é Abraão, quem Isaac, com os personagens alternando-se nas diversas funçóes.

No caso da literatura, também há certo rodízio nas funçóes do sacrificado e do sacrificante, em sua peculiar versão da lógica sacrificial. É possível divisar a exigência da suspensão da ética, por exemplo, quando ocorre a interdição da formulação de perguntas à literatura que não tenham a própria literatura como resposta. Nessa linha, Derrida chega a conjeturar se o dever da irresponsabilidade, de se recusar a responder pela escrita ou pelo próprio pensamento aos poderes constituídos, não seria a forma suprema de responsabilidade.* Contudo, não é apenas ao poder que a literatura recusa uma resposta - é também a qualquer um que formule perguntas a ela. A propósito, não existiriam indagaçóes à literatura sem origem nos poderes constituídos? Não é imaginável algo como uma oposição subalterna à irresponsabilidade da literatura?

$\mathrm{Na}$ mesma entrevista em que aparece a referência ao dever da recusa à resposta, um trecho menos mencionado pelos leitores ressalva que uma instituição anti-institucional pode ser tanto subversiva quanto conservadora, seu conservadorismo podendo vir tanto de sua institucionalidade como de seu caráter anti-institucional ("anarquista”, por exemplo), ${ }^{*}$ voltando a abrir a questão que parece se fechar quando é citada apenas a primeira afirmação. A própria fala na entrevista é emaranhada, cortada pelo reconhecimento de riscos de diversos tipos e atravancada por ressalvas e recuos: A liberdade para dizer tudo é uma arma política muito poderosa, dirá 
Derrida, mas uma arma que pode imediatamente ser neutralizada como ficção. Mesmo assim, o escritor pode, "eu diria até que ele deve, às vezes, exigir certa irresponsabilidade, ao menos no que diz respeito a poderes ideológicos".*

Meu exercício aqui tem sido o de buscar ler trechos como esses mantendo toda sua complexidade, colocando ênfase nas expressóes moduladoras e nas ponderações - o escritor deve "às vezes exigir certa irresponsabilidade, ao menos no que diz respeito a poderes ideológicos" - para tentar encontrar, a partir da consideração da cena da escrita da agonia da mãe, o ponto em que o direito a dizer tudo encontraria, enfim, um limite.

Na mesma entrevista, Derrida dirá que pensara, na adolescência, na literatura como o fim da família (e o começo da interioridade, da intimidade, da crítica...), e que a reivindicação de um direito a ela seria importante mesmo quando a família estivesse sob ameaça. * Se na recordação da adolescência a confiança é recuperada, na cena da Circonfissão a peculiaridade é que a família, mais do que perseguida ou ameaçada, está em vias de extinção. É nesse nó que se situa a literatura de Derrida: entre a importância do princípio do direito a dizer tudo, princípio que representa a possibilidade da emancipação de toda proibição, e, por outro lado, a hesitação, manifesta mais uma vez na resposta de Derrida a uma pergunta, em outro contexto, sobre ameaças à liberdade:

a primeira coisa que é preciso dizer é que não há certeza de que queiramos ser livres. Você vincula a liberdade à esperança, como se o que desejássemos acima de tudo fosse ser livres. Não está nem um pouco claro que seja assim. Eu, por exemplo, náo tenho certeza de querer ser livre, isto é, desapegado. Também tenho vontade de estar ligado, de ser solicitado, e não apenas livre.*

A Circonfissão de Derrida é, dolorosamente, sobre uma liberdade que se anuncia, sem ser desejada: a possibilidade de se ver livre da mãe - expressão que aqui ganha ressonância especial.

Marcos P. Natali possui Mestrado e Doutorado em Literatura Comparada pela Universidade de Chicago e Pós-Doutorado em Literatura Hispano-Americana pela USP. É professor-doutor do Departamento de Teoria Literária e Literatura Comparada da USP e pesquisador do CNPq, com projeto sobre literatura e ética. Publicou o livro A politica da nostalgia: Um estudo das formas do passado e textos sobre José María Arguedas, Roberto Bolaño, Mario Bellatin e teoria pós-colonial. E-mail: <mpnatali@usp.br>
* (Ibidem: 38.)

* (Ibidem: 39.)

* (DERRIDA, Jacques. No escribo sin luz artificial. Trad. Rosario Ibañez e María José Pozo. Madri: Cuatro, Ediciones, 1999: 111.)

Recebido em $15 / 03 / 2013$

Aprovado em 20/03/2013 